\title{
A new genus for the Lesser Moorhen Gallinula angulata Sundevall, 1850 (Aves, Rallidae)
}

\author{
George SANGSTER ${ }^{1}$, Juan Carlos GARCÍA-R ${ }^{2}$ \& Steve A. TREWICK ${ }^{3}$ \\ ${ }^{1}$ Department of Bioinformatics and Genetics, Swedish Museum of Natural History, \\ P.O. Box 50007, SE-104 05 Stockholm, Sweden. \\ corresponding author, Email: g.sangster@planet.nl \\ ${ }^{2}$ Hopkirk Institute, Massey University, Private Bag 11-222, Palmerston North, New Zealand. \\ Email: j.c.garciaramirez@massey.ac.nz \\ ${ }^{3}$ Phoenix Lab, Ecology Group, Institute of Agriculture and Environment, Massey University, \\ Private Bag 11-222, Palmerston North, New Zealand. \\ Email: s.trewick@massey.ac.nz \\ ${ }^{1}$ urn:1sid:zoobank.org:author:18BB564B-CA65-40AF-93AA-932A61843535 \\ 2 urn:lsid:zoobank.org:author:DF883332-5661-4D3D-AABA-1E738E95885D \\ ${ }^{3}$ urn:Isid:zoobank.org:author:EF574EF2-0AA8-4554-8F6E-D75657912974
}

\begin{abstract}
Molecular phylogenetic analysis has demonstrated that the genus Gallinula is not monophyletic and comprises four major lineages. A review of the nomenclature of Gallinula shows that generic names are available for three lineages but that a fourth is as yet unnamed. A new monotypic genus, Paragallinula gen. nov., is described for Lesser Moorhen (Gallinula angulata Sundevall, 1850).
\end{abstract}

Key words. Gallinules, morphology, nomenclature, Paragallinula gen. nov., phylogenetics.

Sangster G., García-R J.C. \& Trewick S.A. 2015. A new genus for the Lesser Moorhen Gallinula angulata Sundevall, 1850 (Aves, Rallidae). European Journal of Taxonomy 153: 1-8. http://dx.doi.org/10.5852/ejt.2015.153

\section{Introduction}

Recent molecular phylogenetic analysis has clarified the relationships among rails and has shown that several currently recognized genera are not monophyletic (García-R et al. 2014a). The study included nuclear and mitochondrial sequence data representing 70 species of rails in 22 of the 33 extant genera, including seven species traditionally placed in Gallinula Brisson, 1760. Gallinula as traditionally circumscribed (e.g., Sibley \& Monroe 1990; Taylor \& van Perlo 1998) was found to be paraphyletic with respect to Fulica Linnaeus, 1758 and Porzana Vieillot, 1816. Spot-flanked Gallinule Gallinula melanops (Vieillot, 1819 ) was sister to three (of eleven) species of Porzana, and two further species of Gallinula (G. mortierii (Du Bus, 1840) and G. ventralis Gould, 1837 were found to be their sister group. Surprisingly, the Lesser Moorhen Gallinula angulata Sundevall, 1850, which until now has always been placed in the genus Gallinula, was resolved as sister to a clade comprising Fulica Linnaeus, 1758 and all other species of Gallinula. These relationships are well-supported and suggest that taxonomic revision is warranted. 
Current knowledge of the phylogenetic relationships among coots and gallinules leaves two major options for the generic assignment of G. angulata. Fulica and several species of Gallinula including G. angulata could be combined in a single genus for which Fulica has nomenclatural priority. Alternatively, G. angulata could be removed from Gallinula and placed in a separate genus. Merging Gallinula with Fulica would result in the change of at least six species names (G. chloropus (Linnaeus, 1758), G. galeata (M.H.C. Lichtenstein, 1818), G. comeri Allen, 1892, G. nesiotis P.L. Sclater, 1861, G. tenebrosa Gould, 1846 and G. angulata), and it would fail to recognise the widely accepted ecological, morphological and phylogenetic distinction between gallinules (Gallinula as defined below) and coots. Placement of $G$. angulata in a separate genus minimises taxonomic instability and maximises the information content of genus limits because it allows Gallinula and Fulica to be retained as separate genera. However, this strategy requires additional adjustments (some of which have already been adopted) to reconcile the systematic status of the gallinules, which are not a natural group. In this paper, we provide an updated molecular phylogeny of the "Fulica" clade (sensu García-R et al. 2014a), including a member of the putative genus "Porphyriornis" (Gallinula nesiotis) which was not previously sampled (García-R et al. 2014a), and a description of morphological characters to propose a new genus for the Lesser Moorhen.

\section{Materials and methods}

We conducted a phylogenetic analysis of the Fulica-clade using the same sequences and methods as García-R et al. (2014a), but also including an available cytochrome $b$ sequence of $G$. nesiotis obtained from GenBank (EF681998) which is the only marker shared between the datasets of Groenenberg et al. (2008) and García-R et al. (2014a). Thus, we conducted Bayesian and Maximum Likelihood analyses of $\sim 2900 \mathrm{bp}$ of mitochondrial DNA (partial sequences of the mitochondrial genes cytochrome $b$, cytochrome oxidase subunit I and 16S ribosomal RNA) and $\sim 1900$ bp of nuclear DNA (fragments of beta-fibrinogen intron 7 and Recombination Activating Gene 1). We rooted the tree using an outgroup comprising species within the "Aramides" clade (García-R et al. 2014a).

We review the nomenclatural status of all generic names applied to Gallinula (sensu Sibley \& Monroe 1990; Taylor \& van Perlo 1998) to assess if any of these apply to G. angulata. The diagnosis of the new genus is based on the morphological dataset of Livezey (1998), which represents the most comprehensive and detailed comparison of morphological variation in rails. Livezey's (1998) study included all extant species of Fulica and Gallinula plus a number of extinct species, including Gallinula nesiotis and Gallinula (Pareudiastes) pacifica (Hartlaub \& Finsch, 1871).

\section{Results}

\section{Phylogenetics}

A phylogeny of the Fulica-clade is shown in Fig. 1. The topology is identical to that of García-R et al. (2014a), but with G. nesiotis added as the sister of G. gallinula and G. galeata. Gallinula (sensu Sibley \& Monroe 1990; Taylor \& van Perlo 1998) was resolved as paraphyletic and comprised four major lineages: (1) G. chloropus, G. galeata, G. nesiotis and G. tenebrosa; (2) G. ventralis and G. mortierii; (3) G. melanops; and (4) G. angulata (Fig. 1).

\section{Nomenclature}

The genus Gallinula Brisson, 1760 has G. chloropus as its type species (lineage 1 in Fig. 1). The synonymy of Gallinula (sensu Sibley \& Monroe 1990; Taylor \& van Perlo 1998) includes at least 10 names, although some of these have been reinstated as valid genera in recent classifications. However, none of these names can be applied to G. angulata. 
Hydrogallina Lacépède, 1799 (type species Fulica chloropus Linnaeus, 1758, currently Gallinula chloropus) and Stagnicola Brehm, 1831 (type species Fulica chloropus Linnaeus, 1758, currently Gallinula chloropus) are junior synonyms of Gallinula.

Tribonyx Du Bus, 1840 (type species Tribonyx mortierii Du Bus, 1840) has been used for two Australian species, Tasmanian Native-hen G. mortierii and Black-tailed Native-hen G. ventralis by some authors (e.g., Christidis \& Boles 2008; Dickinson \& Remsen 2013). Recognition of Tribonyx as a separate genus from Gallinula is supported by phylogenetic studies of morphology (Livezey 1998) and DNA sequences (García-R et al. 2014a), which showed that G. mortierii and G. ventralis are not closely related to other species of Gallinula (lineage 2 in Fig. 1). Neither study indicated a close relationship between these species and Lesser Moorhen, and the name Tribonyx is thus not applicable to G. angulata.

Brachyptrallus Lafresnaye, 1840 (type species Brachyptrallus ralloides Lafresnaye, 1840, currently Tribonyx mortierii Du Bus, 1840) is a junior synonym of Tribonyx and not applicable to G. angulata.

Porphyriops Pucheran, 1845 (type species Fulica crassirostris J.E. Gray, 1829; now Gallinula melanops crassirostris) has been used for the Spot-flanked Gallinule (e.g., Wolters 1975; Blake 1977; Livezey 1998). Its recognition as a separate genus from Gallinula is now supported by phylogenetic studies of morphology (Livezey 1998) and DNA sequences (García-R et al. 2014a) (lineage 3 in Fig. 1). Again, neither study indicated a close relationship between Spot-flanked Gallinule and Lesser Moorhen. Therefore, Porphyriops is not applicable to G. angulata.

Pareudiastes Hartlaub \& Finsch, 1871 (type species Pareudiastes pacificus Hartlaub \& Finsch, 1871) and Edithornis Mayr, 1933 (type species Edithornis silvestris Mayr, 1933) have been proposed as the generic names of Samoan Moorhen and San Cristobal Moorhen, respectively. These two species have

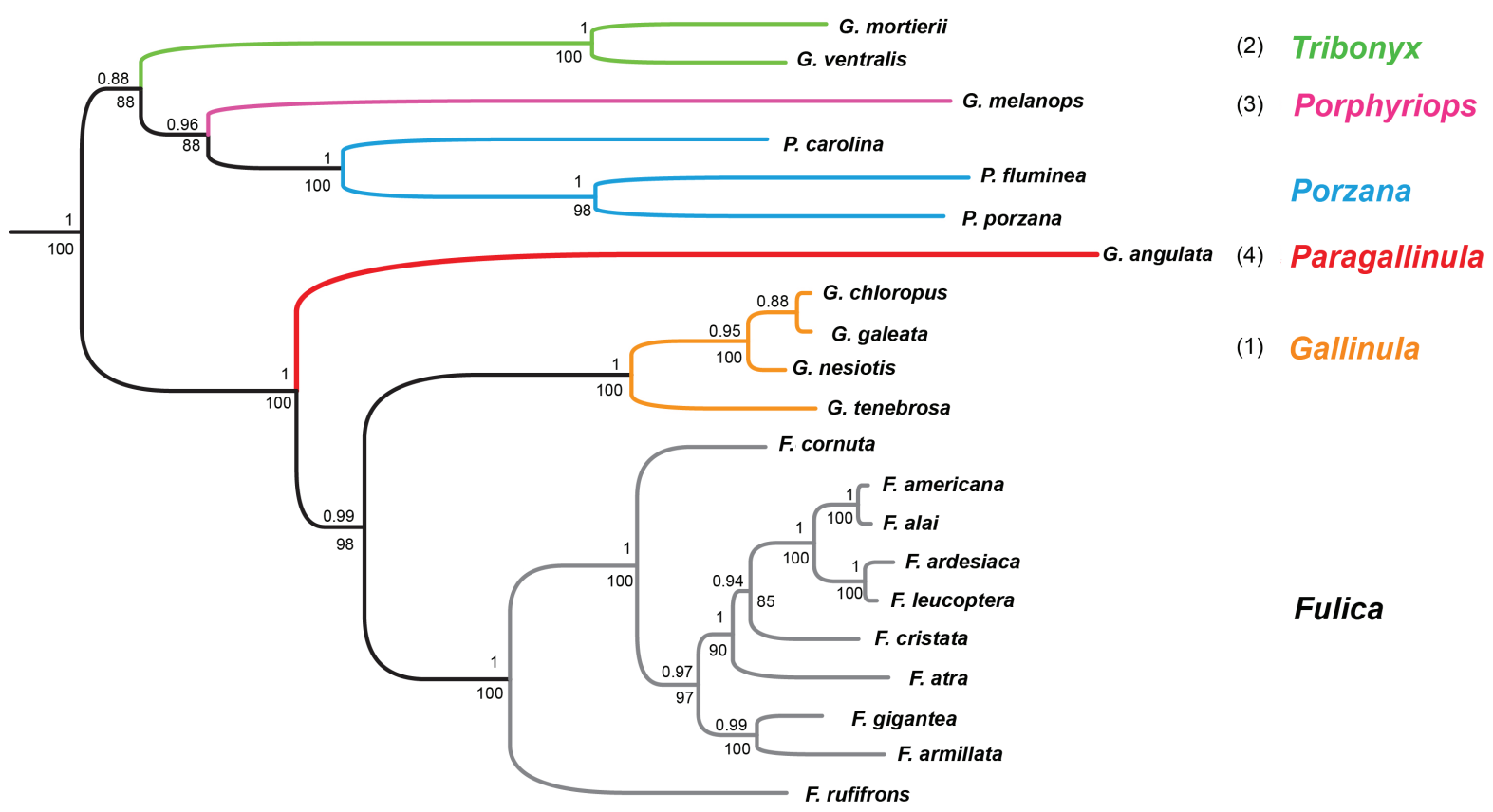

Fig. 1. Bayesian analysis of the Fulica-clade (sensu García-R et al. 2014a). Numbers above nodes indicate posterior probabilities from Bayesian analysis. Numbers below nodes are percent bootstrap values from Maximum Likelihood analysis. Colours indicate relevant clades with current nomenclature at branch tips. Coloured genus names are those adopted here to reconcile phylogeny and known morphological diversity. 
both been placed in Gallinula in the past (e.g., Sibley \& Monroe 1990; Taylor \& van Perlo 1998) but they share a number of unique character states and are now typically combined in the genus Pareudiastes (Olson 1973, 1975a; Livezey 1998; Dickinson \& Remsen 2013). A phylogenetic analysis of morphological characters indicates that G. angulata is not closely related to Pareudiastes (Livezey 1998). In addition, G. angulata does not share any unique apomorphies with Pareudiastes and differs from the latter by at least 14 integumentary characters (listed below). Thus, the name Pareudiastes is not applicable to G. angulata.

Porphyriornis Allen, 1892 (type species Porphyriornis comeri Allen, 1892) is sometimes used as the generic name of Gough Moorhen G. comeri and Tristan Moorhen G. nesiotis (e.g., Peters 1934; Livezey 1998). However, because both species are closely related to G. chloropus, these are typically placed in Gallinula (Wolters 1975; Sibley \& Monroe 1990; Taylor \& van Perlo 1998; Dickinson \& Remsen 2013), an arrangement supported by a molecular phylogenetic study (Groenenberg et al. 2008; see also Fig. 1). Porphyriornis represents a synonym of Gallinula.

Microtribonyx Sharpe, 1893 (type species Gallinula ventralis Gould, 1837) is sometimes used for a monotypic genus comprising T. ventralis (Wolters 1975), but this name is now generally regarded as a synonym of Tribonyx or Gallinula, depending on whether the former is recognised as a separate genus (with two species), as we advocate here.

Pyramida Oliver, 1955 (type species Rallus hodgeni Scarlett, 1955, currently Tribonyx hodgenorum) was proposed for an extinct flightless species, now known from both North and South Island, New Zealand. Subsequently, Scarlett (1970) placed this species in the genus Capellirallus Falla, 1954, whereas Olson (1975b) transferred it to Tribonyx, which he considered a subgenus of Gallinula. In Livezey's (1998) phylogenetic analysis of morphological characters, this species was included within a polytomy comprising Tribonyx, Pareudiastes, Edithornis, Porphyriornis, Gallinula and Fulica. In any case, Pyramida is not applicable to G. angulata.

As no generic name appears to be available for $G$. angulata, we propose a new genus taxon.

Class Aves Linnaeus, 1758

Order Gruiformes (Bonaparte, 1854)

Family Rallidae (Rafinesque, 1815)

Paragallinula gen. nov. urn:1sid:zoobank.org:act:909AC100-559E-4CA3-BC7E-E6FD87002E30

\section{Type species}

Gallinula angulata Sundevall, 1850. Monotypic.

\section{Differential diagnosis}

Paragallinula gen. nov. differs from Gallinula, Pareudiastes, Tribonyx and Porphyriops in that (i) the orange suffusion on the frontal shield does not encompass the entire shield (in Gallinula encompassing entire frontal shield (Fig. 2); in Pareudiastes, Tribonyx and Porphyriops no suffusion of orange). In addition, Paragallinula gen. nov. differs from most species in the Fulica-clade (except $T$. ventralis) in (ii) showing marked sexual plumage dimorphism (Taylor 1996; Taylor \& van Perlo 1998). Paragallinula gen. nov. further differs from Gallinula in (iii) the lack of a contrasting reddish band ("garter") on the legs immediately proximal to the ankle joint (present in Gallinula) (Fig. 2). 
Paragallinula gen. nov. differs from Fulica in (ii) gradual change in colouration on hindneck from dark grey head to paler lower neck and back (abrupt change in Fulica); (iii) absence of broad cutaneous lobes on digits II-IV of feet (present in Fulica); and (iv) presence of narrow cutaneous folds on lateral and medial sides of digits I-IV of feet (absent in Fulica). Paragallinula also differs from Fulica in at least 12 diagnostic osteological characters (characters 120, 124, 125, 127, 139, 216, 274, 298, 311, 312, 316, 343 in Livezey 1998, to which is referred for descriptions of characters and their states).

Paragallinula gen. nov. further differs from the two species of Pareudiastes in (iii) frontal shield with acuminate posterior margin (squared margin in Pareudiastes); (iv) ventroanterior position of nasal depression (ventromedial in Pareudiastes); (v) fully feathered lores (in Pareudiastes, lores with sparsely feathered, yellow-orange area from base of maxilla to orbit); (vi) gradual change in colouration on hindneck from dark grey head to paler lower neck and back (very dark without noticeable change in colour from head to back in Pareudiastes); (vii) flank feathers with large white streaks (no streaks in Pareudiastes); (viii) undertail-coverts white dorsolaterally, black ventromedially (entirely black or brownish-black in Pareudiastes); (ix) six pairs of rectrices (four in Pareudiastes); (x) rectrices forming normally-shaped tail (in Pareudiastes, rectrices very short barely protruding beyond uppertailand undertail-coverts); (xi) leading edge of distalmost primary with narrow white margin (absent in Pareudiastes); (xii) underwing-coverts with white bars (not barred in Pareudiastes); (xiii) bend of wing whitish (no white colouration in Pareudiastes); and (xiv) presence of narrow cutaneous folds on lateral and medial sides of digits I-IV of feet (absent in Pareudiastes).

Paragallinula gen. nov. further differs from Tribonyx in (ii) broad naked area on crown in downy plumage (absent in Tribonyx); (iii) long, filamentous white filoplumes in downy plumage (absent in Tribonyx); (iv) frontal shield with acuminate posterior margin (rounded in Tribonyx); (v) undertail-coverts white dorsolaterally, black ventromedially (entirely blackish in Tribonyx); (vi) six pairs of rectrices (eight in Tribonyx); (vii) underwing-coverts dark grey, blackish or black (medium brown in Tribonyx); and (viii)

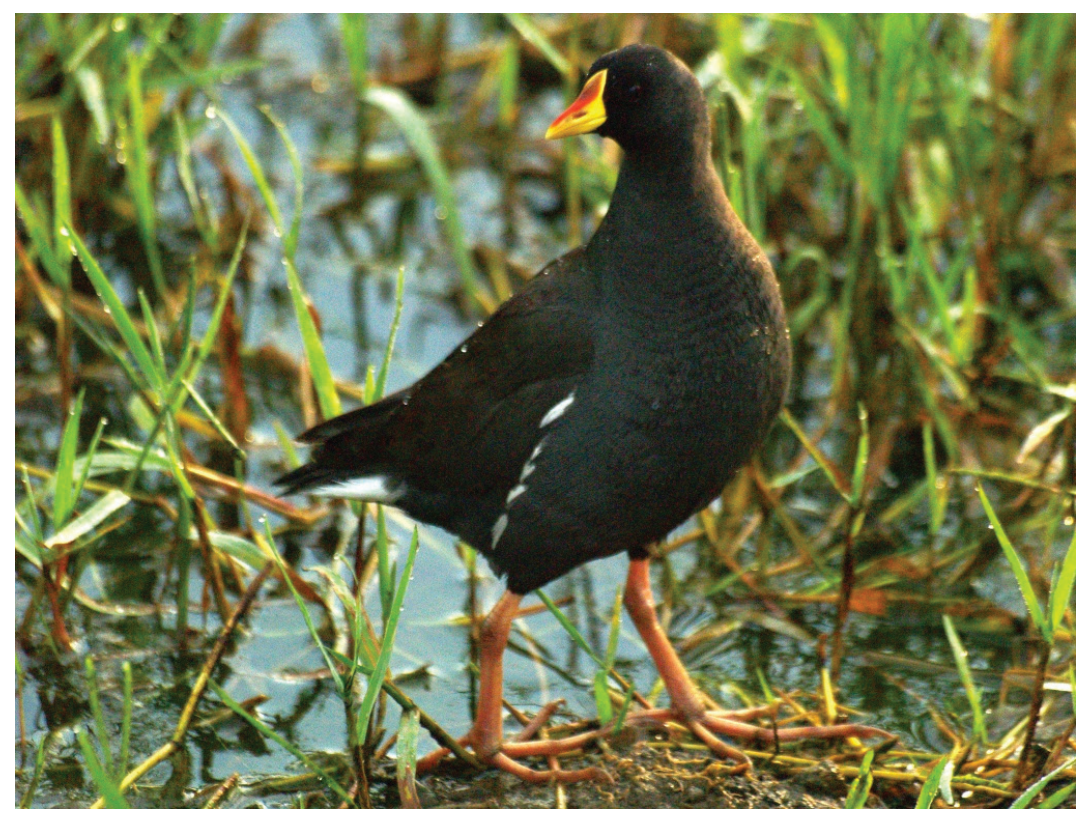

Fig. 2. Lesser Moorhen Paragallinula angulata Sundevall, 1850, Kgomo Kgomo, South Africa, Feb. 2011 (photo by Mark Tittley). This photograph illustrates two diagnostic character states differentiating Paragallinula from the genus Gallinula: the orange colouration on the frontal shield does not cover the entire shield, and the lack of a contrasting reddish band on the legs proximal to the ankle joint. 
bend of wing whitish (no white colouration in Tribonyx). Paragallinula also differs from Tribonyx in a single osteological character: (ix) ossa digitorum pedis, digiti tertius, phalanx intermedialis (secundi) is equal to or longer than phalanx quartus (in Tribonyx modally shorter than phalanx distalis (tertius).

Paragallinula gen. nov. further differs from Porphyriops (P. melanops) in (iii) broad naked area on crown in downy plumage (absent in Porphyriops); (iv) long, filamentous white filoplumes in downy plumage (absent in Porphyriops); (v) ventroanterior position of nasal depression (ventromedial in Porphyriops); (vi) feathers at base of bill, lores and crown not contrasting with rest of head (in Porphyriops contrastingly black); (vii) flank feathers mostly plain but with large white streaks at tips (flank feathers brown-grey, spotted white in Porphyriops); (viii) central belly dark slate-grey (whitish in Porphyriops); (xi) undertailcoverts white dorsolaterally, black ventromedially (white in Porphyriops); and (x) rectrices dark grey or black (brown in Porphyriops). In addition, there are two diagnostic osteological differences between Paragallinula and Porphyriops: (xi) os frontale, facies dorsalis moderately convex (flat or slightly concave in Porphyriops), and (xii) os squamosum, fossa temporalis distinct, separated medially from each other by significantly broad, elevated expanse of os frontale (in Porphyriops, indistinct, shallow, limited to region immediately ventral to processus postorbitalis).

\section{Etymology}

The generic name is derived from the Greek para (beside) and the Latin gallinula (a little hen or chicken). It denotes the resemblance of $P$. angulata to species of Gallinula but highlights that they are independent evolutionary lineages. The gender of the name is feminine.

\section{Distribution}

Paragallinula angulata is found in most of the African continent from Senegal and Gambia to Ethiopia, Namibia, Botswana and South Africa.

\section{Discussion}

In the past, the validity and systematic position of many monotypic genera of birds were problematic. This is because the genera were not based on phylogenetic studies but on subjectively inferred evolutionary distinctiveness which in turn was based on phenotypic distinctiveness and commonly their insular location. Indeed, some taxonomists have placed large numbers of species in monotypic genera for such reasons, but the introduction of molecular phylogenetic methods in avian taxonomy revealed that many of these were nested within other genera (e.g., Johnson et al. 2001; Gibson \& Baker 2012; Alström et al. 2015). The resulting gradual elimination of monotypic genera in many bird groups has enhanced understanding of avian diversification. Conversely, several species have been shown to occupy a phylogenetic position inconsistent with their traditional generic assignment, resulting in the recognition of new monotypic genera (e.g., Chesser et al. 2009; Slager \& Klicka 2014). It is for this latter reason that, to re-circumscribe Gallinula as a monophyletic group and so eliminate its current paraphyly, we erect a new monotypic genus Paragallinula gen. nov. for G. angulata. This reflects the well-supported phylogenetic position of $G$. angulata outside the Gallinula-Fulica clade and avoids the inclusion of five species of Gallinula in the distinctive genus Fulica, and accords with pleas for 'economy of nomenclatural change' (Vences et al. 2013).

The contents of the genus Gallinula have been gradually revised by the transfer of phylogenetically divergent species to other genera. Several species of rails which are still referred as "gallinules" have sometimes been placed in the genus Gallinula, including Allen's (Porphyrio alleni Thomson, 1842), Purple (P. martinicus (Linnaeus, 1766)) and Azure (P. flavirostris (J.F. Gmelin, 1789)) gallinules (e.g., Ripley 1977; Howard \& Moore 1991). Molecular phylogenetic evidence accords with plumage features showing a closer relationship to Porphyrio swamphens and far removed from Gallinula moorhens 
(e.g., typical G. chloropus) (Trewick 1997; García-R et al. 2014a). Such discoveries demonstrate the effect of convergence in body-form and coloration of separate rail lineages on taxonomic inference. Reconciliation using molecular data helps us understand how phenotypic traits evolve in response to ecological conditions, and in this case shows that the informal composition of gallinules is not a natural grouping.

Analysis of the timing and pattern of diversification within Rallidae established on fossils and complete mitochondrial genomes is revealing (García-R et al. 2014a, 2014b). The node that separates Fulica from the most closely related group of Gallinula (including G. chloropus) dates to $18 \mathrm{Mya}$ ( $95 \%$ highest posterior density interval of 10-26 Mya), whereas the mean age of the Fulica group is under 10 Mya. The position of G. angulata as the sister of Fulica and Gallinula indicates that the time of divergence between Lesser Moorhen, Gallinula and Fulica is similar to or exceeds that of several widely accepted genera of rails, including Amaurolimnas Sharpe, 1893 / Aramides Pucheran, 1845, Neocrex Sclater \& Salvin, 1869 / Pardirallus Bonaparte, 1856, Amaurornis Reichenbach, 1853 / Gallicrex Blyth, 1852 and Aramidopsis Sharpe, 1893 / Lewinia G.R. Gray, 1855 (García-R et al. 2014a, 2014b). This further supports that Gallinula and Fulica are best retained as separate genera but that Lesser Moorhen should be placed in a different genus. Our treatment reconciles paraphyly of Gallinula as follows: Gallinula comprising G. chloropus, G. galeata, G. comeri, G. nesiotis and G. tenebrosa; Tribonyx comprising T. ventralis and T. mortierii; Porphyriops melanops; and Paragallinula angulata.

\section{Acknowledgements}

We are grateful to Mark Tittley for permission to use his excellent photograph of the Lesser Moorhen. Two anonymous referees made helpful suggestions, which improved the quality of he manuscript.

\section{References}

Alström P., Jønsson K.A., Fjeldså J., Ödeen A., Ericson P.G.P. \& Irestedt M. 2015. Dramatic niche shifts and morphological change in two insular bird species. Royal Society Open Science 2 (3), 140364. http://dx.doi.org/10.1098/rsos.140364

Blake E.R. 1977. Manual of Neotropical Birds. Vol. 1. University of Chicago Press, Chicago.

Chesser R.T., Claramunt S., Derryberry E. \& Brumfield R.T. 2009. Geocerthia, a new genus of terrestrial ovenbird (Aves: Passeriformes: Furnariidae). Zootaxa 2213: 64-68.

Christidis L. \& Boles W.E. 2008. Systematics and Taxonomy of Australian Birds. CSIRO Publishing, Collingwood, Vic.

Dickinson E.C. \& Remsen J.V. Jr 2013. The Howard and Moore Complete Checklist of the Birds of the World. Fourth edition, Vol. 1: Non-passerines. Aves Press, London.

García-R J.C., Gibb G.C. \& Trewick S.A. 2014a. Deep global evolutionary radiation in birds: Diversification and trait evolution in the cosmopolitan bird family Rallidae. Molecular Phylogenetics and Evolution 81: 96-108. http://dx.doi.org/10.1016/j.ympev.2014.09.008

García-R J.C., Gibb G.C. \& Trewick S.A. 2014b. Eocene diversification of crown group rails (Aves: Gruiformes: Rallidae). PLoS ONE 9 (10): e109635. http://dx.doi.org/10.1371/journal.pone.0109635

Gibson R. \& Baker A.J. 2012. Multiple gene sequences resolve phylogenetic relationships in the shorebird suborder Scolopaci (Aves: Charadriiformes). Molecular Phylogenetics and Evolution 64: 66-72. http://dx.doi.org/10.1016/j.ympev.2012.03.008

Groenenberg D.S.J., Beintema A.J., Dekker R.W.R.J. \& Gittenberger E. 2008. Ancient DNA elucidates the controversy about the flightless island hens (Gallinula sp.) of Tristan da Cunha. PLoS ONE 3(3): e1835. http://dx.doi.org/10.1371/journal.pone.0001835 
Howard R. \& Moore A. 1991. A Complete Checklist of the Birds of the World. Second Edition. Academic Press, London.

Johnson K.P., de Kort S., Dinwoodey K., Mateman A.C., ten Cate C., Lessells C.M. \& Clayton D.H. 2001. A molecular phylogeny of the dove genera Streptopelia and Columba. The Auk 118: 874887. http://dx.doi.org/10.1642/0004-8038(2001)118[0874:AMPOTD]2.0.CO;2

Livezey B.C. 1998. A phylogenetic analysis of the Gruiformes (Aves) based on morphological characters, with an emphasis on the rails (Rallidae). Philosophical Transactions of the Royal Society of London B 353: 2077-2151. http://dx.doi.org/10.1098/rstb.1998.0353

Olson S.L. 1973. A classification of the Rallidae. Wilson Bulletin 85: 381-416.

Olson S.L. 1975a. The South Pacific gallinules of the genus Pareudiastes. Wilson Bulletin 87: 1-5.

Olson S.L. 1975b. A review of the extinct rails of the New Zealand region (Aves: Rallidae). National Museum of New Zealand Records 1: 63-79.

Peters J.L. 1934. Check-list of Birds of the World. Vol. 2. Museum of Comparative Zoology, Cambridge, Massachusetts.

Ripley S.D. 1977. Rails of the World. Dodine, Boston.

Scarlett R.J. 1970. The genus Capellirallus. Notornis 17: 303-319.

Sibley C.G. \& Monroe B.L. 1990. Distribution and Taxonomy of Birds of the World. Yale University Press, New Haven.

Slager D.L. \& Klicka J. 2014. A new genus for the American Tree Sparrow (Aves: Passeriformes: Passerellidae). Zootaxa 3821: 398-400. http://dx.doi.org/10.11646/zootaxa.3821.3.9

Taylor P.B. 1996. Family Rallidae (rails, gallinules and coots). In: del Hoyo J., Elliot A. \& Sargatal J. (eds) Handbook of the Birds of the World. Vol. 3. Hoatzin to auks: 108-209. Lynx Edicions, Barcelona.

Taylor P.B. \& van Perlo B. 1998. Rails, a Guide to the Rails, Crakes, Gallinules and Coots of the World. Pica Press, Sussex.

Trewick S.A. 1997. Flightlessness and phylogeny amongst endemic rails (Aves: Rallidae) of the New Zealand region. Philosophical Transactions of the Royal Society of London B 352: 429-446.

Vences M., Guayasamin J.M., Miralles A. \& De La Riva I. 2013. To name or not to name: Criteria to promote economy of change in Linnaean classification schemes. Zootaxa 3636: 201-244. http://dx.doi. org/10.11646/zootaxa.3636.2.1

Wolters H.E. 1975. Die Vogelarten der Erde. Eine systematische Liste mit Verbreitungsangaben sowie deutschen und englischen Namen. Part 1: 1-80. Paul Parey, Hamburg.

Manuscript received: 3 September 2015

Manuscript accepted: 8 October 2015

Published on: 16 November 2015

Topic editor: Rudy Jocqué

Desk editor: Kristiaan Hoedemakers

Printed versions of all papers are also deposited in the libraries of the institutes that are members of the EJT consortium: Muséum national d'Histoire naturelle, Paris, France; Botanic Garden Meise, Belgium; Royal Museum for Central Africa, Tervuren, Belgium; Natural History Museum, London, United Kingdom; Royal Belgian Institute of Natural Sciences, Brussels, Belgium; Natural History Museum of Denmark, Copenhagen, Denmark. 